\title{
A novel GNAS mutation in an infant boy with pseudohypoparathyroidism type la and normal serum calcium and phosphate levels
}

\author{
Mutação nova no GNAS em um menino com \\ pseudo-hipoparatireoidismo tipo la e dosagens \\ séricas normais de cálcio e fósforo
}

1 Diseases Unit Osteometabolic, Endocrinology Service, Hospital das Clínicas, Faculdade de Medicina, Universidade de São Paulo (HC-FMUSP), São Paulo, SP, Brazil ${ }^{2}$ Laboratório de Hormônios e Genética Molecular (LIM/42) Division of Endocrinology, FMUSP, São Paulo, SP, Brazil

${ }^{3}$ Unidad Endocrinología Infantil, Servicio de Pediatría, Pontificia Universidad Católica de Chile, Santiago, Chile

Correspondence to: Regina Matsunaga Martin Av. Dr. Enéas de Carvalho Aguiar, 155 PAMB, $2^{\circ}$ andar, Bloco 6 05403-900 - São Paulo, SP, Brazil reginamm@usp.br

Received on Aug/1/2010 Accepted on Nov/17/2010
Mariana Tenorio Antunes Reis ${ }^{1,2}$, Andreina Cattani ${ }^{3}$, Berenice Bilharinho Mendonca ${ }^{2}$, Pedro Henrique Silveira Corrêa', Regina Matsunaga Martin ${ }^{1,2}$

\section{SUMMARY}

The objective of this study was to describe a new mutation in GNAS in a family with pseudohypoparathyroidism type la (PHP la), a rare osteometabolic disease. An 8-month-old boy was seen by an Endocrinologist due to obesity and low growth velocity. Noteworthy, his mother exhibited typical Albright hereditary osteodystrophy (AHO) phenotype. The clinical diagnosis of PHP la was suspected. The GNAS coding region from mother and son was amplified and directly sequenced. A novel heterozygous missense mutation (c.673T>C) was identified in exon 5 in both patients. In this family, the mother's clinical picture was the clue for the son's diagnosis. Molecular analysis of GNAS confirmed the diagnosis of PHP la in both patients and the child's early diagnosis was possible. Moreover, this novel missense substitution expands the spectrum of GNAS mutations associated with this disorder and allows for genetic counseling of this family. Arq Bras Endocrinol Metab. 2010;54(8):728-31

\section{SUMÁRIO}

O objetivo deste estudo foi descrever uma nova mutação no GNAS em uma família com pseudo-hipoparatireoidismo tipo la (PHP la), doença osteometabólica rara. Um garoto de oito meses foi visto por um endocrinologista por obesidade e baixa velocidade de crescimento. Chamava a atenção o fato de sua mãe apresentar fenótipo típico da osteodistrofia hereditária de Albright (OHA). O diagnóstico clínico de PHP la foi suspeitado. A região codificadora do GNAS da mãe e do filho foi amplificada e submetida ao sequenciamento direto. Uma nova mutação missense em heterozigose (c.673T>C) foi identificada no éxon 5 em ambos. 0 quadro clínico materno foi a pista para o diagnóstico do filho. A análise molecular do GNAS confirmou o diagnóstico de PHP la nos dois pacientes possibilitando o diagnóstico precoce da criança. Além disso, essa nova substituição missense expande o espectro de mutações no GNAS associadas a essa doença e permite o aconselhamento genético nesta família. Arq Bras Endocrinol Metab. 2010;54(8):728-31

\section{INTRODUCTION}

I n 1942, Fuller Albright and cols. described the first human disease attributed to hormonal resistance, which was named pseudohypoparathyroidism (PHP). This condition has the same biochemical features as hypoparathyroidism, except for the elevation of PTH (1).
PHP is a rare, sporadic or familial disorder that is classified into two types according to the renal response to exogenous PTH administration: PHP type I (PHP I), when urinary cyclic adenosine monophosphate (cAMP) excretion and phosphaturic response are reduced (compared to normal subjects), and PHP type 
II (PHP II), when urinary cAMP excretion is normal but the phosphaturic response is absent. Lastly, PHP I is divided into subtypes Ia, Ib and Ic based on different phenotypes, genetic findings and pathogenesis. The cause of these subtypes is mutations or imprinting abnormalities in the stimulatory alpha-subunit G protein $\left(\mathrm{G}_{\mathrm{s}} \alpha\right)$ whose signaling is essential for the actions of PTH and of many other hormones (2).

PHP Ia is characterized by resistance to PTH and to several additional hormones that bind to G proteincoupled receptors (GPCRs). Affected patients display variable developmental and somatic features known as Albright hereditary osteodystrophy (AHO), which comprises obesity, short stature, brachydactyly, round face, ectopic ossification and/or mental retardation. Most of the PHP Ia patients have a loss-of-function of $\mathrm{G}_{\mathrm{s}} \alpha$ due to a maternal heterozygous mutation in exons $1-13$ of GNAS, the gene responsible for encoding $\mathrm{G}_{\mathrm{s}} \alpha(3)$.

The same mutations found in GNAS leading to PHP Ia are found in patients with pseudopseudohypoparathyroidism (PPHP), who display AHO features without hormonal resistance, so one family can present cases of PHP Ia and PPHP. The determination of which one is going to be found depends on parental origin, meaning that subjects that inherited GNAS mutations from the mother exhibit PHP Ia whereas those who inherited the same mutations from the father exhibit PPHP. This inheritance pattern is consistent with paternal imprint of $\mathrm{G}_{\mathrm{s}} \alpha(4)$.

In this paper, we present a family in which the mother has AHO features and hypocalcemia symptoms while her son has obesity and low growth velocity. Based on the mother's clinical picture, diagnosis of PHP Ia was suspected and confirmed after complementary tests and the suspicion that her son had the same disease (PHP Ia) was raised. To validate this, the aim of this study was to search for mutations in GNAS in both individuals to establish the molecular etiology of PHP Ia and its heritability.

\section{SUBJECT AND METHODS}

\section{Case report}

The proband was a term newborn, weighting 3,400 g and measuring $47 \mathrm{~cm}$, without history of perinatal complications. At 8 months, he was admitted to the Endocrinology Unit of Universidad Catolica in Chile due to obesity and low growth velocity. His physical examination showed a weight of $11.44 \mathrm{~kg}(\mathrm{SD}=+2.19)$, stature of $68.2 \mathrm{~cm}(\mathrm{SD}=-0.78)$, body mass index $(\mathrm{BMI})$ of $24.6 \mathrm{~kg} / \mathrm{m}^{2}$ (weight-for-length percentile $>$ P97), without any other alterations. At that time, hypothyroidism was diagnosed and treated with levothyroxine.

Noteworthy, his mother (Figure 1) exhibited typical AHO phenotype such as short stature, round face, short neck and brachydactyly. In addition, she had paresthesia, hypothyroidism and basal nucleus calcification on cranial CT scan. These data and her laboratorial profile (Table 1) were compatible with PHP Ia.

Although the patient had normal serum concentrations of calcium and phosphate for his age, the diagnosis of PHP Ia was suspected because of his elevated levels of PTH and his mother's background (Tables 1 and 2). To confirm this possibility, the GNAS coding region of both patients was studied.

\section{Molecular analysis}

The study protocol was approved by the ethics committee, and the informed consent was obtained from the parents. After obtaining written informed consent for the study, peripheral blood leukocytes genomic DNA was extracted from the patient and his mother. Ten intronic primer pairs were used to amplify exons 1-13 from the $G N A S$ gene. After amplification confirmation by electrophoresis in agarosis gel, PCR products were submitted to automatic sequencing reaction. The results were compared to the wild type GNAS sequence published at www.ensembl.org (ENST00000371085).

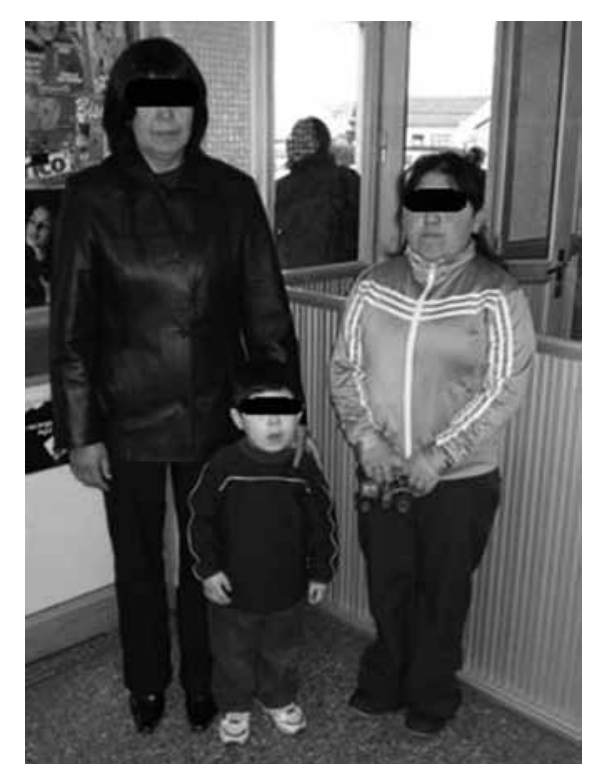

Figure 1. Patient at 3.3 years of age, his mother and his unaffected grandmother. 
Table 1. Mother's laboratorial profile

\begin{tabular}{lcc}
\hline Analyte & Adult normal range & Result \\
\hline $\mathrm{Ca}$ & $8.8-10.2 \mathrm{mg} / \mathrm{dL}$ & 7.6 \\
$\mathrm{P}$ & $2.3-4.6 \mathrm{mg} / \mathrm{dL}$ & 4.6 \\
$\mathrm{PTH}$ & $11-62 \mathrm{pg} / \mathrm{mL}$ & 691 \\
\hline
\end{tabular}

Table 2. Patient's laboratorial profile

\begin{tabular}{lccccc}
\hline \multirow{2}{*}{ Analyte } & \multirow{2}{*}{$\begin{array}{c}\text { Child } \\
\text { normal range }\end{array}$} & \multicolumn{5}{c}{ Chronological age } \\
\cline { 3 - 6 } & $\mathbf{9 ~ m}$ & $\mathbf{1} \mathbf{1} \mathbf{2} \mathbf{~ y r s}$ & $\mathbf{2} \mathbf{1} \mathbf{2} \mathbf{~ y r s}$ & $\mathbf{5} \mathbf{3} \mathbf{4} \mathbf{~ r s}$ \\
\hline TSH & $0.8-6.3 \mathrm{uU} / \mathrm{mL}$ & 16.6 & 4.9 & 1.7 & 0.1 \\
T4 & $7.3-15.3 \mathrm{ug} / \mathrm{dL}$ & 8.1 & 11.0 & 11.1 & 11.7 \\
T3 & $105-296 \mathrm{ng} / \mathrm{dL}$ & 202 & & & \\
FT4 & $0.7-1.5 \mathrm{ng} / \mathrm{dL}$ & 1.1 & & & \\
Ca & $8.8-10.8 \mathrm{mg} / \mathrm{dL}$ & 9.8 & 9.7 & 8.9 & 9.2 \\
P & $5.0-10.8 \mathrm{mg} / \mathrm{dL}$ & 6.6 & 6.3 & 5.5 & 5.5 \\
PTH & $11-62 \mathrm{pg} / \mathrm{mL}$ & & 132 & 87 & 144 \\
\hline
\end{tabular}

\section{RESULTS}

A novel heterozygous missense mutation was identified in exon 5 of GNAS in the proband: a substitution of $\mathrm{T}$ $\rightarrow \mathrm{C}$ at nucleotide 673 (c.673T>C), leading to an amino acid (aa) replacement in codon 106 of isoleucine $\rightarrow$ threonine (p.1106T). His mother had the same mutation confirming the proband's mutation origin (Figure 2).
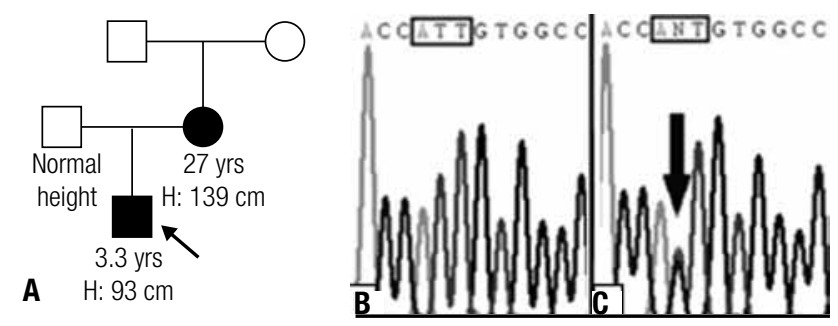

Figure 2. (A) Pedigree of the family. Electropherograms of part of GNAS exon 5 from a normal control (B) and the child sample (C); the arrow shows the substitution $T \rightarrow C$, in heterozygous, that was also detected in the mother's child; the small boxes highlight the codon 106.

\section{DISCUSSION}

In this report, we present a patient with initial complaints of obesity and low growth velocity, in whom the initial laboratorial alterations were hypothyroidism without evidence of thyroid autoimmunity (negative thyroid autoantibodies). The patient had normal calcium and phosphate levels, which did not lead to suspicion of PHP at first. However, his mother had typi- cal features of AHO, symptoms of hypocalcemia and resistance to TSH, which were the clues for the son's diagnosis.

Although hypocalcemia is one of the most prominent features in PHP Ia, some patients have been reported to have normocalcemia. To explain this finding, Tamada and cols. (5) consider at least two hypothesis: a dietary intake rich in calcium and increased serum concentrations of active vitamin $\mathrm{D}$, or bone responsiveness to PTH may compensate for hypocalcemia. In the latter, bone demineralization has been reported to occur frequently in PHP Ia and Ib, however, clinically significant hyperparathyroid bone disease with radiologic or histologic features of osteitis fibrosa cystica is uncommon (5).

In this case, the patient was only one and a half years old when PTH levels were measured for the first time. So, we believe that the patient was still normocalcemic as PHP Ia diagnosis was precocious. The raised PTH concentrations suggest PTH resistance and he would probably have developed hypocalcemia and its symptoms if calcium and vitamin $\mathrm{D}$ supplementation were not introduced.

Because $G_{s} \alpha$ inheritance pattern is consistent with the parental origin-specificity, it is known that PHP Ia results from a heterozygous inactivating mutation at GNAS inherited from the maternal allele while PPHP results from a mutation in the paternal allele (6). Thus, in the family studied, $\mathrm{G}_{\mathrm{s}} \alpha$ proband's mutation was maternally inherited and this is consistent with PHP Ia. Not surprisingly, normocalcemia combined with the AHO phenotype could be misdiagnosed as PPHP.

A different substitution in the same codon (p.I106S) within $\mathrm{G}_{\mathrm{s}} \alpha$ coding region was previously described as the cause of PHP Ia in an infant boy. The clinical findings of congenital hypothyroidism, calcinosis cutis and AHO phenotype during infancy were the reasons to consider that diagnosis. As for the boy described here, this patient had normocalcemia and elevated PTH levels at 7 months, however, our patient does not have skin lesions. The authors think that p.Il06S substitution results in a defective $\mathrm{G}_{\mathrm{s}} \alpha$ because the residue Ile106 is located within the helical domain of the protein, which is considered a regulator and activator of its function. Moreover, the part within the helical domain that extends from residue 70 to 140 is functionally important for adenylyl cyclase activation. In addition, substitution of the hydrophobic aa isoleucine by the polar aa serine probably leads to $\mathrm{G}_{\mathrm{s}} \alpha$ impaired function, as a 
Table 3. Multiple sequence alignment of GNAS in different species

\begin{tabular}{lcccc}
\hline Animals & Species & Protein Acc. & Gene & Protein sequence \\
\hline Human & Homo sapiens & NP_536350.2 & GNAS & NNLKEAIETIVAAMSNLVP \\
Chimpanzee & P. troglodytes & XP_525370.2 & GNAS & NNLKEAIETIVAAMSNLVP \\
Dog & Canis lupus familiaris & NP_001003263.1 & GNAS & NNLKEAIETIVAAMSNLVP \\
Cattle & Bos taurus & NP_851364.1 & GNAS & NNLKEAIETIVAAMSNLVP \\
Red jungle fowl & Gallus gallus & XP_001231580.1 & GNAS & NNIKEAIETIVTAMGNLAP \\
Zebrafish & Danio rerio & XP_685500.2 & LOC557353 & NNIKEAIETIVTAMSVLVP \\
Fruit fly & D. melanogaster & NP_477506.1 & G-Salpha60A & KNIRDAILTITGAMSTLNP \\
Mosquito & A. gambiae & XP_320433.1 & AgaP_AGAP012095 & KNIRDAILTITGAMSTLTP \\
Roundworm & C. elegans & NP_490817.3 & gsa-1 & RNVRDAMQVILRAMDEIVP \\
\hline
\end{tabular}

The residue lle-106 (I) is shown in bold at "protein sequence" column.

result of conformational changes within its helical domain, affecting adenylyl cyclase activation for example. Furthermore, the "variant" allele type (p.I106S) was not found in over 100 analyzed alleles from healthy controls of German descent suggesting that it is not a polymorphism (7).

For the same reasons, we speculate that the substitution p.I106T is also the causative mutation of our patient even without performing a functional study. In both cases, serine and threonine are polar aa in opposition to isoleucine which is a hydrophobic aa. Furthermore, the correspondent human residue Ile-106 of $\mathrm{G}_{\mathrm{s}} \alpha$ is highly conserved in different species such as the chimpanzee, dog, cow, chicken, zebrafish, fruit fly, mosquito and roundworm (C. elegans), indicating that a replacement of this aa may be deleterious. Table 3 shows the alignment generated by the MUSCLE software (8).

The presence of AHO features and normocalcemia does not always mean PPHP, especially if the mutation is maternally inherited. In the latter case, the correct diagnosis is PHP Ia and follow-up calcium and PTH levels should be recommended in order to start early treatment.

In our study case, the mother's clinical picture allowed the child's precocious diagnosis of PHP Ia and genetic counseling for this family. In both patients, PHP Ia was due to a novel missense mutation in the GNAS gene (p.I106S) in the heterozygous state.

Although PHP is a rare disorder, in many cases, clinical manifestations are insidious and even if hypocalcemia symptoms are evident, sometimes the condition can be misdiagnosed as epilepsy. Therefore, its preco- cious diagnosis and treatment are important to minimize the development of complications such as basal nuclei calcification, cataract, as well as the consequences of wrong treatment.

Disclosure: no potential conflict of interest relevant to this article was reported.

\section{REFERENCES}

1. De Sanctis L, Romagnolo D, Olivero M, Buzi F, Maghnie M, Scire $\mathrm{G}$, et al. Molecular analysis of the GNAS1 gene for the correct diagnosis of Albright hereditary osteodystrophy and pseudohypoparathyroidism. Pediatr Res. 2003;53(5):749-55.

2. Donghi V, Mora S, Zamproni I, Chiumello G, Weber G. Pseudohypoparathyroidism, an often delayed diagnosis: a case series. Cases J. 2009;2:6734.

3. Mantovani G, de Sanctis L, Barbieri AM, Elli FM, Bollati V, Vaira $V$, et al. Pseudohypoparathyroidism and GNAS epigenetic defects: clinical evaluation of Albright hereditary osteodystrophy and molecular analysis in 40 patients. J Clin Endocrinol Metab. 2010;95(2):651-8.

4. Mantovani G, Bondioni S, Locatelli M, Pedroni C, Lania AG, Ferrante $E$, et al. Biallelic expression of the Gsalpha gene in human bone and adipose tissue. J Clin Endocrinol Metab. 2004;89(12):6316-9.

5. Tamada Y, Kanda S, Suzuki H, Tajima T, Nishiyama T. A pseudohypoparathyroidism type la patient with normocalcemia. Endocr J. 2008;55(1):169-73.

6. Linglart A, Mahon MJ, Kerachian MA, Berlach DM, Hendy GN, Juppner $\mathrm{H}$, et al. Coding GNAS mutations leading to hormone resistance impair in vitro agonist- and cholera toxin-induced adenosine cyclic $3^{\prime}, 5^{\prime}$-monophosphate formation mediated by human XLalphas. Endocrinology. 2006;147(5):2253-62.

7. Riepe FG, Ahrens W, Krone N, Folster-Holst R, Brasch J, Sippell WG, et al. Early manifestation of calcinosis cutis in pseudohypoparathyroidism type la associated with a novel mutation in the GNAS gene. Eur J Endocrinol. 2005;152(4):515-9.

8. Edgar RC. MUSCLE: multiple sequence alignment with high accuracy and high throughput. Nucleic Acids Res. 2004;32(5):1792-7. 